\title{
Active Participation in a Sci-Tech Community: Collaborative Peer Review
}

\section{Matthew Armstrong}

Kyushu University

\section{Tanya McCarthy \\ Kyoto University}

\section{Reference Data}

Armstrong, M. I., \& McCarthy, T. M. (2021). Active participation in a sci-tech community: Collaborative peer review. In P. Clements, R. Derrah, \& P. Ferguson (Eds.), Communities of teachers \& learners. JALT. https://doi.org/10.37546/JALTPCP2020-27

Active participation in learning is a central concept in many higher education institutions in Japan. For science and technology students in particular, learning approaches that promote collaboration, self-regulatory practices, and critical thinking in the L2, are especially encouraged in order to help prepare students for real-life research and/or professional situations. A collaborative learning initiative, iLearn, is introduced in this paper, which aims to help raise awareness of the qualities of good scientific writing and presentations by encouraging critical evaluation of authentic research through peer-review practices. Methodologically, the researchers examined peer-review exchanges of scientific posters and papers and then used content analysis to identify, categorize, and analyze meaningful exchanges. The authors concluded that it is worthwhile to implement collaborative programs that can help sci-tech learners to participate effectively in international and intercultural settings.

日本の多くの高等教育機関において、アクティブラーニングは中心的な概念となっている。とりわけ、科学技術(sci-tech)を 専攻する学生にとつて、実際の研究や就職後の状況に備えて、L2での協同作業、自己調整の実践、批判的思考を促進する学習 アプローチは高く推奨されている。本研究では、査読行為を通して本格的な研究に批判的評価を行うことで、優れた科学的文 章やプレゼンテーションの質に対する意識を高めることを目的とした協同学習の取り組み(iLearn)を紹介する。研究方法と しては、科学ポスターや論文の査読を内容分析によって考察し、有益なやり取りの分類を行った。本論は、sci-techの学習者が 国際的·異文化的な環境に効果的に参加できるような協同学習プログラムを実施することは有意義であると結論づける。
The notion of bridging the gap between classroom learning and real-life contextual situations is the ideal learning environment for many universities. A major problem facing these universities, however, is that EFL courses usually focus on teaching general academic skills with few opportunities to transfer knowledge or apply these skills to situations outside the classroom walls. Curricula which require teamwork and help students to critically reflect on learning are useful for students to gain knowledge of potential challenges they may encounter in the real world. Currently, lectures, seminars, and labs are the main styles of instruction for Japanese science and technology (scitech) majors. Curricular structures including authenticity, joint problem-solving, collaborative and/or self-regulatory practices are typically conducted in the students' L1 but less so in the L2. However, to prepare students to compete in professional industry or academic settings of conferencing, networking, and publishing, it is important to introduce authentic tasks into L2 learning. The authors felt that a collaborative learning approach would be effective in providing the necessary opportunities to foster authentic knowledge construction and promote meaningful interaction, as well as encourage individual self-regulatory behavior. This article reports on an initiative called iLearn in which an informal learning environment was created for early career academics and researchers to help raise awareness of the qualities of good scientific writing and presentations individually and collaboratively.

\section{Collaborative Learning and Self-Regulation}

Collaborative learning has been broadly defined as "a situation in which two or more people learn or attempt to learn something together" (Dillenbourg, 1999, p. 1). More specifically, within this educational approach, learners cognitively engage with learning materials and peers through meaningful exchanges to find solutions to challenges they may face in real-life situations. Collaborative learning further encourages students to 
drive their own inquiry based on individual learning goals, as they learn how to work with others to produce projects that reflect specific skills and knowledge. This kind of socially situated learning environment involves a dynamic and psychological interaction between peers, materials, and meaningful learning activities, which is key to developing self-regulatory practices. For Hadwin et al. (2018) and Zimmerman (2002), self-regulated learning refers to individuals taking personal responsibility over their learning in an iterative process. That is, setting a learning goal, making a plan of action, evaluating performance, and then reflecting on the outcome before setting another goal. In this program, learners' goals were to improve speaking and writing skills for conferences. Thus, specific tasks were designed that would enable learners to successfully achieve their goals.

Collaborative task engagement such as text reconstruction, jigsaw information gap activity, or translation are typical activities employed in EFL settings to engage learners with acquiring a second language. For sci-tech students interested in improving research for professional contexts, learning activities that simulate real-world encounters must be designed to reflect this scenario. In particular, the authors found discussion circles, networking sessions, and peer review on research proposals, papers, and posters to be the most suitable tasks for collaborative and social engagement. Peer-review, in particular, proved to be the most suitable task to trigger learning mechanisms (Dillenbourg, 1999), as learners were able to critically reflect on and evaluate their own and other students' performance.

\section{Peer Review}

Peer review, in essence, aims to improve overall learning by developing students' ability to work in pairs or small groups to critically evaluate and improve the quality of an oral or written assignment. An increasing number of studies have highlighted the benefits of developing peer-review skills (Cho \& Cho, 2011; Cho \& MacArthur, 2011; Hyland \& Hyland, 2006; Lundstrom \& Baker, 2009; Søndergaard \& Mulder, 2012; Yalch et al., 2019). Over the years, however, there has been a change in focus from its merits to a focus on how to increase its effectiveness in the EFL classroom (McCarthy \& Armstrong, 2019; Ruegg, 2014; Yangin-Eksi, 2012). More recent studies conducted with sci-tech majors (see, for example, Da Costa et al., 2018; Dowse et al., 2018; Pearce et al., 2009) indicate the importance of developing strong peer-review skills to improve learners' ability to respond at a professional level. To develop as early career academics and researchers, it is essential that students understand the conventions of research writing (Mullen, 2006), and how to critically appraise scientific papers and presentations (Fischer \& Zigmond,
1998), as well as how to maintain the integrity of scientific research to produce original, high-quality research products.

Various kinds of sci-tech courses have been designed to help develop early career researchers' skills. Surratt's (2006) oral/written communication course, for example, involved teaching self-evaluation techniques and having students critique peers graduate research papers. While this course aimed to develop students' ability to improve evaluative and critical thinking research skills, it failed to focus on the dialogic interaction. The framework designed by Chittum and Bryant (2014), which incorporated professional peer review into interdisciplinary graduate school curricula, employed mentors to assist students. With the mentor's assistance, students examined not only research conventions but analyzed professional phrasing (specifically jargon, terminology, and tone/manner). Due to budgetary and time constraints in most Japanese universities, hiring adjunct instructors/mentors to provide students with this level of guidance may not be possible. Therefore, engaging students in professional peer review dialogic activities is a practical solution to help them gain the knowledge they require for real-life settings. The ultimate goal for the iLearn program was that this kind of reallife professional experience would ensure that when students submitted an abstract for a conference or a manuscript to a scientific journal, they would be equipped with the necessary tools and knowledge to be successful.

\section{iLearn Implementation}

The Appendix shows the flexible organization of iLearn sessions, and the collaborative tasks designed to engage learners in meaningful dialogue. The program culminated in a final poster presentation and submission of a final paper (short abstract, extended abstract, conference proposal, or short paper) to a website. The focus on poster or paper (or both) depended on learner needs, proficiency level, and how far along students were in their research. Undergraduate science students, for example, who had not yet started research, were instructed in how to develop a paper and poster for an international presentation. For advanced students who were preparing for an international conference, the learning materials for the workshop were student-generated and the authors took on a greater role of a facilitator rather than as an instructor. Eight intensive sessions over four days facilitated by the researchers focused on maximum interaction and collaboration:

- group sessions encouraged intercultural connections, networking practice, and peer feedback 
- informal chat sessions provided time for casual interaction and asking questions

- Google documents offered a platform to practice peer review on papers and posters

Feedback comments extracted from Google Docs were the principal source of data used in this study. The authors first modeled appropriate constructive criticism by giving detailed feedback on an authentic research paper and poster. This enabled the students to understand the specific criteria for self-evaluation and peer review. The key point emphasized to students was that their feedback comments should be constructive, critical, and based on academic conventions. As there was no teacher-directed learning outcome as in a classroom setting, students were encouraged to consider their own individual learning needs for scientific networking and conferencing contexts and provide feedback accordingly.

\section{Data Collection}

Twenty-three Japanese and international students from various research disciplines participated in this study. As part of a funded research project ${ }^{1}$, permission had to be granted from the institutions and participants before collecting data. Most participants were in the process of conducting their own research experiments for a master's or doctoral degree. Japanese learners were proficient English language learners, at about levels B2 to C1 on the CEFR scale. This meant that they were capable of expressing themselves well on a variety of general as well as unfamiliar topics. International students were, for the most part, fluent in English. The main challenge for all students was the lack of English skills when communicating about their research topics. In order to move from general academic topics to more cognitively demanding research-based learning materials, interaction had to be more meaningful. The socio-constructivist theories from Vygotsky (1978) highlighted the role of interaction in the development of cognitive abilities. In his most widely known concept of the zone of proximal development (ZPD), Vygotsky proposed that learners could realize their full potential if given appropriate guidance at the correct time during problem-solving and collaborative tasks. In essence, if the learner is close to mastering a skill, guidance from capable peers along with practice can help them to perform the actions independently. For this reason, the role of meaningful dialogue in students' interactions became central to determining the quality of performance.
As previously stated, data was collected from detailed feedback that was given on shared Google documents. As every student had a Google account, Google Docs was the easiest tool for students to view and comment on each other's work and for the researchers to monitor the quality of learner exchanges. If students were able to give meaningful advice that resulted in student uptake, then it was considered a successful indicator that the learners had a deep understanding of good scientific writing and poster principles and practices.

\section{Data Analysis and Discussion}

Content analysis of peer-review exchanges of posters and scientific papers helped the authors to identify, categorize, and analyze meaningful exchanges between students. First, the authors had to define and identify meaningful exchanges. This referred specifically to exchanges of knowledge or critical reflection on learning that advanced the dialogue and showed students' understanding of the learning materials in the sessions. More explicitly, the authors felt that these exchanges had to be meaningful in a reallife research, academic, or professional context (presentation, networking, publishing) rather than simply an exchange of information (basic greetings, encouraging comment, or sharing of personal information). Meaningful comments were then sorted into units based on categories taught during the sessions and converted to quantitative data. What the authors were looking for, first of all, was students' capacity to move beyond surfacelevel feedback (mechanics-grammar, spelling, and/or vocabulary) to deeper-level, critical feedback on research content (Filius et al., 2018); and secondly, the delivery of the dialogic interactions (specifically the language and tone) as they gave feedback (Yallop \& Leijen, 2018).

\section{Quantitative Analysis of Feedback Comments}

Utterances that highlighted the four taught conventions were sorted into the following categories: (1) Formatting, which referred to general organization and layout; (2) Mechanics, which focused on lexical choices, syntax, and spelling; (3) Content, which examined the research hypothesis, soundness of methodological procedure and data collection, and logic and accuracy of data analysis; and (4) Design, which consisted of comments about poster visuals and ease of understanding of tables and figures in papers The percentage breakdown of utterances in the four categories is shown in Figure 1. 
JALT2020

COMMUNITIES OF
TEACHERS \& IEARNERS

Figure 1

Meaningful Exchanges: Scientific Posters and Papers

\section{Meaningful Exchanges: Scientific Poster}

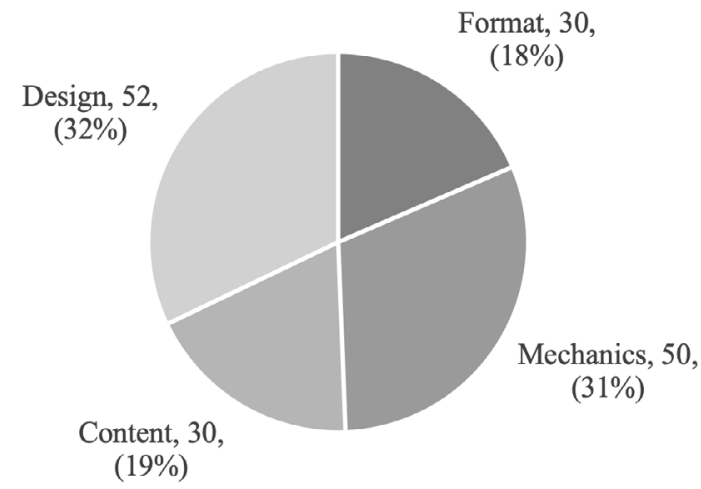

Meaningful Exchanges: Scientific Paper Design, 15 $(6 \%)$

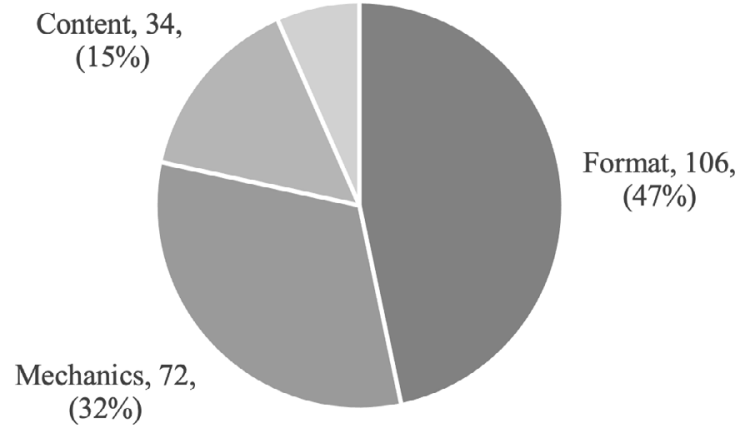

It can be observed that students gave many surface-level comments (Mechanics), which did not encourage critical reflection, rather than deeper level feedback, which required greater levels of conscious processing. Surface-level feedback (especially grammar and spelling error correction) is one of the most frequent forms of feedback in academic writing studies, as it is considered to be simpler to process. At only $31 \%$ for posters and $32 \%$ for papers, however, this was atypical to research in this area which generally sees higher levels of surface-level feedback (see, for example, Ting \& Qian, 2010; Yangin-Eksi, 2012). The authors presume that with more and more accuracy in editing software today, it is likely that the percentage of surface feedback will continue to be reduced. Throughout the peer-review process, students simply suggested tools such as Grammarly ${ }^{2}$ as a means of checking simple grammatical errors by themselves. Comments on formatting were significantly higher for research papers (47\%) than posters $(18 \%)$, as there are strict conventions regarding scientific papers. When designing posters, conventions are more subjective and dependent on specific fields of study. More importance is placed on the visual aspect; thus, the percentage of comments on design (32\%) was naturally higher than comments about figures and tables in a research paper (6\%). Although the researchers had hoped that content feedback (19\% for posters and $13 \%$ for papers) would be higher, this result was also unsurprising as the time restrictions for giving feedback over four days did not allow for deeper analysis. This is possibly another reason for the most significant gap in results in formatting at $18 \%$ for posters and $47 \%$ for papers. For peer reviewers, formatting errors in lengthy research papers was the simplest category to focus on given the time constraints.

Qualitative Analysis of the Discourse of Peer Review

The discourse of peer review has been examined in various ways such as reviewers' use of direct intervention, suggestions, commands, criticisms, hedging, or encouragement (Kourilova, 1998; Wärnsby et al., 2018). Three salient points which emerged from the content analysis of peer-review comments were the consistency in feedback pattern, affective language, and students' professionalism.

\section{Feedback Pattern}

Students' style of feedback followed a similar style to the example used by the researchers as a model in the first session: Positive comment-critical feedback on specific areas to improve-closing comment. This technique, commonly referred to as "sandwich feedback" (Parkes et al., 2013), has not been sufficiently proven to positively impact performance, but in an intensive, four-day intercultural research environment, it was considered to be an effective technique to quickly teach good practices in delivering feedback. 
Positive comment: Students generally began with an informal greeting, positive comment about the overall project, and/or thanks to other students for the advice they received on their writing and posters.

Your poster is very nice (mandatory positive appraisal)..

Thank you for your comments. The design and content of your poster looks really good to me, so I will just give some minor comments:

Hi XXX! I am going to give you some feedback, hope these advices [sic] will be of some value to you, but just know that any changes ultimately will be yours to make.

Critical or corrective feedback: Students gave specific comments about areas to improve in the four-set criteria, followed by an expanded explanation (suggestion, rather than a correction) or request for clarification.

I really like the visual aspect. The font is unique but easy to read, and the colour palette is aesthetically pleasing.

It would be nice if you not only give a comment about studying habit [sic], but tie them again to their sleeping habits. The correlation between sleeping habit and studying habit [sic] need to be reinforced in my opinion.

I honestly got confused at this point, because before this, I had thought that you considered engineering, agriculture, and ISI to all be in the STEM field. Unless you had meant, "tend to be in an engineering major", then its [sic] fine.

There are numerous grammatical errors that you can use Grammarly to identify and fix.

For the majority of students, exchanges were precise, focused, and detailed. Regarding lexical choices and grammar, in particular, international students commented more on nuances in expression that could have affected meaning whereas Japanese students focused more closely on grammatical errors.

I felt the expression "hugging with the same sex" was grammatically questionable I'm not a native speaker, so I'm not sure, but I tried to look up a little on my own, and this expression didn't hit. yeah, my previous comment on "ability to wake up" applies here because, students who can't wake up are just dead. If my Japanese is correct, it should translate to 起き られない [okirarenai meaning “cannot get up”].

Closing comment: At the end of their feedback comments, students closed with various informal or formal expressions.

That's all, I hope this helped.

Good luck :D

I hope I am giving good advices [sic]. Keep up the good work!

That about wraps it up. They're just minor changes but I think they're worth making to help your poster look even better. You've done a great job, and I wish you all the best for your final version.

\section{Affective Language}

Peer reviews generally contained positively glossed responses which were worded with great care and thought. Students avoided harsh critiques by offering words of praise, using various forms of hedging language, making suggestions, adding smiley face emoticons, and reminding the writer that the final decision was ultimately up to them (see Nelson \& Schunn's 2009 study on cognitive and affective discourse features for more detail). This avoided any awkwardness and preserved relationships.

This is only a personal opinion, but $\mathrm{l}$ think...

Maybe your layout can be more centered I suppose, but your decision ultimately comes first in terms of design.

I'd be careful with this claim because its [sic] not directly shown in the results.

I would think that you haven't quite finished with the arrangement? Because it is a bit inconsistent.

Hi XXX, I would like to give you some comments about your paper, I hope you will take to it kindly. 
I think you can make your essay more persuasive if you do this... <-- this is my intuition, so if you mind, please ignore it.

As the authors did not explicitly teach students the art of constructive discourse for peer review, the examples above indicate that the students already had a high level of maturity and self-awareness that would be critical for real-world, professional interactions.

\section{Professionalism}

It was quite interesting to see the degree of formality in some of the language exchanges between writer and reviewer. The decision to use a specific tone or register when conveying information depends on the writer's perception of the audience and context. This meant that the students viewed their peers as research colleagues rather than simply classmates, and as such responded in an appropriate manner as seen from the following exchange:

A: I am very sorry for the delayed response. I apologise for keeping you waiting without any contact from my side, and I understand if it's too late to make any changes to your poster now but I still felt the need to post my comments so I have asked the professor for an extension on the posting deadline. Again, my sincerest apologies for the delay and I hope you can consider even some of these suggestions.... Sorry if it seems a little too long winded, it's only some linguistic choices that, in my opinion, would make this poster look more professional than it already is and shouldn't be too hard to implement. Again, the poster is still very good, and I wish you all the best for your final version!

B: Dear XXX, Not at all, but I reflected them [sic] as much as possible.

A: I'm glad you were able to fit the changes in! Apologies again for the late notice. The data is also easier to read, I like the way you've marked out and highlighted the important parts. I have no further comments to offer, but about the citation I think it may be worth confirming with the professor just in case since it was mentioned as one of the required criteria.

Although the expression, "Dear ," is somewhat unconventional here (as it is typically used in formal letter writing or email), this extract effectively showed students' individual efforts to improve their language skills from general academic language to a higher, more professional standard (related to Vygotsky's ZPD). Areas of disagreement were also handled with a surprising amount of professionalism and showed the researchers that the content was learned deeply as students could defend their knowledge of academic conventions.

I think you've done a [sic] great work with your research paper already! My only suggestion is the formatting if [sic] the paragraphs of your paper; some of the beginning sentences of the paragraphs are tabbed while some are not. Other than that, you're good to go! Good luck!

That is how you are supposed to do it tho [sic]. The first paragraph of a section should not be tabbed while the rest should be...it seemed like the APA style guide disagrees...according to the APA sample paper (attached), it should.

Regardless of the level of feedback, students' comments were, for the most part, on target, highly reflective, and the level of uptake and/or discussion about the comments was high.

\section{Conclusion}

Given the limitations of traditional methods in teaching research practices in the L2 to Japanese sci-tech students, it is important to implement programs that can help prepare learners to present for international conferences, publish their research, and interact in intercultural settings with ease. For the researchers, a collaborative peer-review program (iLearn) became the solution to help sci-tech students acquire the professional knowledge and experiences needed to perform successfully in their research activities, as well as engage positively with authentic language learning and develop a more critical research eye. There is enough evidence in current L2 literature to posit that collaborative learning practices are beneficial in activating cognitive, socio-cognitive, metacognitive, and affective processes, which is conducive to successful learning. One of the concerns in this study noted by the researchers, however, was the quantity of one-way communication between writer and reviewer rather than a twoway, iterative dialogic process. The strength of peer review lies in the construction of knowledge through dialogue, as typically it is the giver that benefits from using higher-order thinking processes (Lundstrom \& Baker, 2009; Webb, 1989). Therefore, for the researchers (and those interested in implementing peer review programs), it is 
imperative that the focus be placed on improving meaningful two-way dialogue rather than asking students to simply give critical feedback. Notwithstanding, based on the analysis of meaningful exchanges in peers' dialogic interactions, it can be concluded that programs such as iLearn can help sci-tech students understand how to critically evaluate their own and their peer's learning performance, become more socially connected to students in different fields, increase intercultural awareness, and prepare them to act in a professional manner in real-life contexts.

While individual departments may continue to conduct active learning exercises in their labs, it is rare to find an informal research environment in which young academics and researchers from various fields of study can gather, meet, network, and share their research in a relaxed setting. Although there are difficulties in implementing such a program, mostly the time required for organizing and facilitating workshops, events, and interactions, it is worth the effort to first, improve collaboration between research students and within faculties and second, increase students' confidence and motivation to present their research to a worldwide audience. As students' attitudes towards specific learning activities are generally contingent upon their ability, willingness, and motivation to learn and experience new things, offering an environment would be a good starting point for those who would like to engage sci-tech students in authentic, out of class learning activities.

\section{Notes}

1. Ministry of Education, Culture, Sports, Science, and Technology (MEXT), Grantin-Aid for Scientific Research (KAKENHI), Project 19K00791/Facilitating Scientific Research and Intercultural Exchange through TaLL

2. Grammarly is a digital writing assistance tool based on artificial intelligence and natural language processing.

\section{Bio Data}

Matthew I. Armstrong is an associate professor in the Faculty of Languages and Cultures at Kyushu University. His research interests lie mainly in the area of curriculum development. His current research focuses on the use of authentic materials in the L2 classroom, and how to engage students in critical peer review practices. <armstrong@flc. kyushu-u.ac.jp>
Tanya M. McCarthy earned a PhD in Linguistics from Macquarie University and is currently employed at Kyoto University. She has been involved with learner development for the past 20 years and continues to pursue research on how to engage learners in meaningful dialogue within the classroom, as well as beyond the classroom walls. $<$ mccarthy.tanyamiranda.7n@kyoto-u.ac.jp >

\section{References}

Chittum, J. R., \& Bryant, L. H. (2014). Reviewing to learn: Graduate student participation in the professional peer-review process to improve academic writing skills. International Journal of Teaching and Learning in Higher Education, 26(3), 473-484. https://files.eric.ed.gov/fulltext/ EJ1060832.pdf

Cho, Y. H., \& Cho, K. (2011). Peer reviewers learn from giving comments. Instructional Science, 39(5), 629-643. https://doi.org/10.1007/s11251-010-9146-1

Cho, K., \& MacArthur, C. (2011). Learning by reviewing. Journal of Educational Psychology, 103(1), 73-84. Available from https://doi.org/10.1037/a0021950

Da Costa, M. P., Oliveira, J., \& Abdulmalik, J. (2018). Where can early career researchers learn how to peer review a scientific paper? European Science Editing, 44(1), 4-7. https://doi.org/10.20316/ ESE.2018.44.17017

Dillenbourg, P. (1999). What do you mean by collaborative learning? In P. Dillenbourg (Ed). Collaborative-learning: Cognitive and computational approaches (pp.1-19). Oxford Elsevier.

Dowse, R., Melvold, J., \& McGrath, K. (2018). Students guiding students: Integrating student peer review into a large first year science subject. A Practice Report. Student Success, 9(3), 79-86. https://doi.org/10.5204/ssj.v9i3.471

Filius, R. M., de Kleijn, R., Uijl, S. G., Prins, F. J., van Rijen, H., \& Grobbee, D. E. (2018). Strengthening dialogic peer feedback aiming for deep learning in SPOCs. Computers \& Education, 125, 86-100. https://doi.org/10.1016/j.compedu.2018.06.004

Fischer, B. A., \& Zigmond, M. J. (1998). Survival skills for graduate school and beyond. New Directions for Higher Education, 101, 29-40. Available from https://doi.org/10.1002/he.10103

Hadwin, A., Järvelä, S., \& Miller, M. (2018). Self-regulation, co-regulation, and shared regulation in collaborative learning environments. In D. H. Schunk \& J. A. Greene (Eds.), Educational psychology handbook series. Handbook of self-regulation of learning and performance (pp. 83-106). Routledge/Taylor \& Francis Group.

Hyland, K., \& Hyland, F. (2006). Feedback on second language students' writing. Language Teaching, 39(2), 83-101. Available from https://doi.org/10.1017/S0261444806003399 
Kourilova, M. (1998). Communicative characteristics of reviews of scientific papers written by nonnative users of English. Endocrine Regulations, 32, 107-114. https://www.sav.sk/journals/endo/ full/er0298g.pdf

Lundstrom, K., \& Baker, W. (2009). To give is better than to receive: The benefits of peer review to the reviewer's own writing. Journal of Second Language Writing, 18(1), 30-43. Available from https://doi.org/10.1016/j.jslw.2008.06.002

McCarthy, T. M., \& Armstrong, M. I. (2019). Peer-Assisted Learning: Revisiting the dyadic interaction process in $\mathrm{L} 2$ academic writing. Asian EFL Journal, 21(3), 6-25. https://www. elejournals.com/asian-efl-journal/asian-efl-journal-volume-23-issue-3-1-may-2019/

Mullen, C. A. (2006). Best writing practices for graduate students: Reducing the discomfort of the blank screen. Kappa Delta Pi Record, 43(1), 30-35. https://doi.org/10.1080/00228958.2006.10516 456

Nelson, M. M., \& Schunn, C. D. (2009). The nature of feedback: How different types of peer feedback affect writing performance. Instructional Science, 37(4), 375-401. https://doi. org/10.1007/s11251-008-9053-x

Parkes, J., Abercrombie, S., \& McCarty, T. (2013). Feedback sandwiches affect perceptions but not performance. Advances in Health Sciences Education volume, 18, 397-407. https://doi.org/10.1007/ s10459-012-9377-9

Pearce, J., Mulder, R., \& Baik, C. (2009). Involving students in peer review. Case studies and practical strategies for university teaching. Centre for the Study of Higher Education. Retrieved from https://www.academia.edu/971160/Involving_students_in_peer_review_Case_studies and_practical_strategies_for_university_teaching

Ruegg, R. (2014). The effect of assessment of peer feedback on the quantity and quality of feedback given. Papers in Language Testing and Assessment, 3(1), 24-43. http://www.altaanz.org/ uploads/5/9/0/8/5908292/3_ruegg.pdf

Søndergaard, H., \& Mulder, R. A. (2012). Collaborative learning through formative peer review: Pedagogy, programs and potential. Computer Science Education, 22(4), 1-25. Available from https://doi.org/10.1080/08993408.2012.728041

Surratt, C. (2006). Creation of a graduate oral/written communication skills course. American Journal of Pharmaceutical Education, 70(1), 5. . https://www.ncbi.nlm.nih.gov/pmc/articles/ PMC1636900/

Ting, M., \& Qian, Y. (2010). A case study of peer feedback in a Chinese EFL writing classroom. Chinese Journal of Applied Linguistics, 33(4), 87-98. Available from https://caod.oriprobe.com/ issues/1570965/toc.htm

Vygotsky, L. S. (1978). Mind in society: The development of higher psychological processes. Harvard University Press.
Wärnsby, A., Kauppinen, A., Aull, L., Leijen, D., \& Moxley, J. (2018). Affective language in studen peer reviews. Journal of Academic Writing, 8, 28-53. https://doi.org/10.18552/joaw.v8i1.429

Webb, N. M. (1989). Peer interaction and learning in small groups. International Journal of Educational Research, 13, 21-39. Available from https://doi.org/10.1016/0883-0355(89)90014-1

Yalch, M. M., Vitale, E. M., \& Ford, J. K. (2019). Benefits of peer review on students' writing. Psychology Learning \& Teaching, 18(3), 317-325. Available from https://doi. org $/ 10.1177 / 1475725719835070$

Yallop, R., \& Leijen, D. (2018). The perceived effectiveness of written peer feedback comments within L2 English academic writing courses. Eesti Rakenduslingvistika Ühingu aastaraamat [Estonian Papers in Applied Linguistics], 14, 247-271. https://doi.org/10.5128/ERYa14.15

Yangin-Eksi, G. (2012). Peer review versus teacher feedback in process writing: How effective? International Journal of Applied Educational Studies, 13(1), 33-48. https://www.researchgate.net/ publication/321905974_Peer_Review_versus_Teacher_Feedback_in_Process_Writing_How Effective/citations

Zimmerman, B. J. (2002). Becoming a self-regulated learner: An overview. Theory Into Practice, 41(2), 64-70. Available from https://doi.org/10.1207/s15430421tip4102_2

\section{Appendix}

iLearn Organization and Dialogic Components

\begin{tabular}{|c|c|c|c|}
\hline Session & Research Poster & Research Paper & Dialogic Tasks \\
\hline $\begin{array}{c}1 \\
\text { Introductions }\end{array}$ & $\begin{array}{l}\text { Introduce model } \\
\text { and structure of } \\
\text { scientific poster }\end{array}$ & $\begin{array}{l}\text { Introduce model } \\
\text { scientific paper } \\
\text { - Review basic } \\
\text { structure of } \\
\text { extended abstract } \\
\text { or short research } \\
\text { paper }\end{array}$ & - Networking \\
\hline $\begin{array}{c}2 \\
\text { Research } \\
\text { background }\end{array}$ & $\begin{array}{l}\text { Research hypothesis } \\
\text { and questions } \\
\text { for academic or } \\
\text { scientific topics }\end{array}$ & $\begin{array}{l}\text { Review basics } \\
\text { of quotation, } \\
\text { paraphrase, and } \\
\text { summary }\end{array}$ & $\begin{array}{l}\text { - Group discussion } \\
\text { on research aims, } \\
\text { hypothesis }\end{array}$ \\
\hline
\end{tabular}




\section{JALT2020}

COMMUNITIES OF
TEACHERS \& IEARNERS

\begin{tabular}{|c|c|c|c|}
\hline Session & Research Poster & Research Paper & Dialogic Tasks \\
\hline $\begin{array}{l}3 \\
\text { Research } \\
\text { method }\end{array}$ & $\begin{array}{l}\text { Poster formatting } \\
\text { (layout, font, colors) }\end{array}$ & $\begin{array}{l}\text { Review } \\
\text { introduction and } \\
\text { methodology) }\end{array}$ & $\begin{array}{l}\text { Peer review } \\
\text { of research } \\
\text { background, } \\
\text { research } \\
\text { methodology, and } \\
\text { poster outline }\end{array}$ \\
\hline $\begin{array}{c}4 \\
\text { Research data }\end{array}$ & $\begin{array}{l}\text { Selecting the } \\
\text { best visuals when } \\
\text { presenting scientific } \\
\text { data }\end{array}$ & $\begin{array}{l}\text { Review results and } \\
\text { data analysis }\end{array}$ & $\begin{array}{l}\text { Peer review of data } \\
\text { collection methods } \\
\text { and analysis; and } \\
\text { poster visuals }\end{array}$ \\
\hline $\begin{array}{c}5 \\
\text { Peer-Review }\end{array}$ & $\begin{array}{l}\text { Self-evaluation of } \\
\text { poster using the set } \\
\text { criteria }\end{array}$ & $\begin{array}{l}\text { Self-evaluation of } \\
\text { paper using the set } \\
\text { criteria }\end{array}$ & $\begin{array}{l}\text { Peer review of } \\
\text { poster and paper } \\
\text { (Draft } 1)\end{array}$ \\
\hline $\begin{array}{c}6 \\
\text { Practice } 1\end{array}$ & $\begin{array}{l}\text { Poster presentation } \\
\text { practice } 1 \text { and Q\&A }\end{array}$ & $\begin{array}{l}\text { Final peer review } \\
\text { and critical } \\
\text { discussion on } \\
\text { revised paper }\end{array}$ & $\begin{array}{l}\text { - Group feedback } \\
\text { - Networking } 1\end{array}$ \\
\hline $\begin{array}{c}7 \\
\text { Practice } 2\end{array}$ & $\begin{array}{l}\text { Poster presentation } \\
\text { practice } 2 \text { and Q\&A }\end{array}$ & $\begin{array}{l}\text { Paper submission to } \\
\text { mock website }\end{array}$ & $\begin{array}{l}\text { - Group feedback } \\
\text { - Networking } 2\end{array}$ \\
\hline $\begin{array}{c}8 \\
\text { Final }\end{array}$ & $\begin{array}{l}\text { Mock international } \\
\text { presentation and } \\
\text { networking event }\end{array}$ & $\begin{array}{l}\text { Conference booklet } \\
\text { with short abstracts } \\
\text { and biodata }\end{array}$ & - Networking \\
\hline
\end{tabular}

Armstrong \& McCarthy: Active Participation in a Sci-Tech Community: Collaborative Peer Review 